\title{
PRO MENTE OBERÖSTERREICH - INCLUSION INSTEAD OF EXCLUSION
}

\author{
Dominik Gruber ${ }^{1}$, Werner Schöny ${ }^{1}$ \& Kurosch Yazdi $^{2}$ \\ ${ }^{\prime}$ pro mente OÖ, Lonstorferplatz 1, 4020 Linz, Austria \\ ${ }^{2}$ Department of Psychiatry - Specialization Addiction Medicine, Kepler University Hospital Linz, Austria
}

received: 25.1.2017;

revised: 3.5.2017;

accepted: 7.7.2017

\section{SUMMARY}

pro mente $O \ddot{O}$ is one of the biggest organisations offering psycho-social care and treatment. It is a crucial part of the differentiated system of social psychiatric services in Austria. First, the article describes the organization pro mente OÖ, its history and services. Then, a selection of framework conditions of social psychiatric supply is presented. In this respect some existing strengths and weaknesses of the Austrian psycho-social supply system are discussed.

Key words: pro mente - social psychiatric supply - supply conditions - Austria

\section{pro mente Oberösterreich: the organisation and its history}

pro mente OÖ (Oberösterreich; translated: Upper Austria) is an organisation that professionally supports people with mental health problems through providing comprehensive supply services. Since its foundation it constitutes itself as a apolitical, interdenominational and non-profit organisation. pro mente OÖ was founded in 1964 by the medical director of the former WagnerJauregg psychiatric hospital in Linz (nowadays known as "Neuromed Campus of the Kepler University Clinic Linz") Otto Schnopfhagen. The founding name was "pro mente infirmis". The aim of the newly founded organisation was to make the disregard of people with mental illnesses a subject of public discussion. The later was reached through setting up outpatient follow-up care which provided the possibility to bring affected people back into society (for a comprehensive description of the history see pro mente OÖ 2014).

The foundation of pro mente OÖ can be seen, together with similar ambitions in Vienna, as the initial impulse for the development of the modern social psychiatry in Austria. The other seven federal provinces were to follow by and by and in the end, due to efforts of the leading provinces Upper Austria, Salzburg and Vienna, they merged into the umbrella organisation "pro mente Austria" without losing their federal independence (pro mente Austria 2017).

The organisation has had its current name "pro mente OÖ. Gesellschaft für psychische und soziale Gesundheit" (translated: "pro mente Upper Austria. Association for psychological and social health") since 1996. This title is the result of several renamings and a developing process away from a negative attitude dealing with health deficits towards an approach of seeing the concerns and needs of affected people. A landmark decision for this change constitutes the so called "Ottawa Charta for Health Promotion" (1986). The WHO passed this Charta in order to promote health in everyday life, instead of illnesses (WHO 1986).

In the late 1960s and in the early 1970s "pro mente OÖ" already set up some psycho-social structures. During that time pro mente OÖ built up the first counselling centres and protected workshops outside the hospital walls. Throughout the 1970s the expansion of social psychiatric services was extended. In 1976 the first so called "patient club" was set up in order to support patients in everyday life after a hospital stay. In the early 1980s the first "LaienhelferInnen" (voluntary laypeople) took up their work as "buddies", which was a further step towards the so called "Tetralog", the idea that participation can only work through involving affected people, professional supporters, relatives and the general public.

In 1988 Werner Schöny took over as head of pro mente OÖ. In the 1990s pro mente OÖ expanded its psycho-social services all over Upper Austria, especially in the countryside. Housing facilities were transformed from residential halls into smaller living units. The two leading principles "close to the community" and "outpatient rather than in-patient" have influenced the care. In that time pro mente OÖ started to build up an autonomous network of clients with the aim of selfrepresentation for affected people (advocacy group). This organisation, named "strada OÖ", represents the collective interests of the "clients" and runs projects, for example cafe bars and sales shops.

In the 1970s in Austria, as in many European countries, the process of "dehospitalisation" had started. By the end of the 1990s the last chronically affected people were released from hospital into new, innovative forms of living and support in Upper Austria. The process of "dehospitalisation" finally came to an end in 2003. The result of the evaluation showed that the care and support of formerly "hospitalised" people was cheaper and there 
were no cuts concerning life quality (Grausgruber et al. 2006). Nowadays, psychiatric inpatient treatment solely aims at providing urgent treatment.

A key element in the development of the social psychiatric care in Upper Austria is the close linking of human resources and services between in-hospital and "community close" psychiatric treatment and services. Currently pro mente OÖ is one of the biggest organisations offering psycho-social care and treatment in Austria. The organisation supports around 34.000 people annually. It has got approximately 1.500 employees, working in around 200 locations and sites, such as living, mobile care, leisure time and communication, rehabilitation and counselling. Nonetheless, one of the main goals of pro mente OÖ is "inclusion", the idea of equal participation for people with disabilities in all fields of society.

\section{Framework conditions of social psychiatric supply in Austria}

As every other organisation pro mente OÖ has to adhere to certain framework conditions, when supporting people with mental illnesses. Thus the following section presents a selection of legal and financial requirements of pro mente OÖ. In the final part the social psychiatric care structure that evolved in Upper Austria is dealt with.

\section{Legal framework conditions}

Mexico initiated negotiations on the "UN Convention on the Rights of Persons with Disabilities" (CRPD) in 2001. The talks ended in 2006, when the convention was finally adopted by the UN general assembly (Weiß 2006). In Austria the CRPD was ratified in 2008. Thus the state of Austria, the federal provinces, as well as the municipalities are obliged to implement the CRPD (BMASK 2010). As a result the so called "Nationale Aktionsplan Behinderung 2012-2020" (translated: "national plan of action for disability 2012-2020") was launched in 2012 (BMASK 2012). According to this publication an inclusive society should be reached by 2020. In this society all people, including people with disabilities, can participate in all levels of this society.

Upper Austria has already implemented large parts of this plan through the introduction of the so called "Oberösterreichisches Chancengleichheitsgesetz" (translated: "Upper Austrian law to reach equal opportunities") in 2008. This law affects all people with disabilities, such as mental, psychological, physical ones or a combination of the listed, living in Upper Austria. Affected people are legally entitled to certain services, such as therapy, living and employment. However, if the financial situation allows it, the person has to pay parts of the cost himself/herself. Some supplementary services, such as psycho-social consultation or leisure and sports activities, are still available for free. Nevertheless, a lot of people in Upper Austria, who would have a legal claim, lack services at all or at least adequate ones. 2014 around 3.400 people are on a waiting list for residences or living units. On the contrary there are only around 4.700 people who are taken care off in this section (coverage rate: $58 \%$ ) (Land Oberösterreich 2015). The reasons for this low coverage rate are diverse. Partly there is an undersupply of services. But one can reasonably assume that only a part of those, who are on the waiting list, actually have an urgent demand for such services.

Along with implementing the law of equal opportunities in Upper Austria advocacy groups were installed. Thus elected people who are physically or mentally handicapped do have the possibility to advocate the interests of handicapped people and participate on different political levels. In order to being able to fulfill their assignments these elected people receive trainings. Furthermore they get all costs related to their function refunded, such as e.g. travel expenses, costs of office supplies. For pro mente OÖ all this is coordinated by the organisation "strada OÖ".

Aside from these positive effects this comprehensive legal right also has unintended consequences. So Upper Austria was forced to build up a complex administration to put the law into practice and to handle the large amount of legal claims. In sum this has led to more bureaucracy and to less flexibility in supplying social psychiatric services. Nevertheless it is to be hoped that the quality of the mental health system will continue to rise, but without the requirement that the people affected have to pay more for supply.

\section{Financial framework conditions}

In Austria the topics of "health" and "social issues" are separated both in organisational and financial terms. The section "social issues" is usually responsible for people with disabilities. Furthermore it is important to know that Austria is a federal structured state. Thus competencies and assignments, both of the health system as with social issues, are divided between the state and the federal provinces. The "social budget" of Upper Austria has continually risen since the 1980s. In 1985 Upper Austria spent around 77 million Euros for social issues (Öberösterreichische Nachrichten 2016), whereas this figure rose up to 558 million Euros in 2015 (Land Oberösterreich 2015). Considering the 1.5 million inhabitants of Upper Austria around 370 Euros are spent per person annually. The majority of the annual "social budget" - around $80 \%$ - are used for the services of the law to reach equal opportunities ("Chancengleichheitsgesetz") (ibid.). The reasons for this significant increase of the "social budget" are e.g. the increasing average age of the population and the constant developing social system. One aspect is the permanent improvement of the quality of the social system in the area of services for disabled and in the area of psycho-social prevention and follow up care (Oberösterreichische Nachrichten 2016). Therefore, there has been an on-going (political) discussion over the rising costs and possible cost-saving options. Due to political decisions in Upper Austria pro mente OÖ has been forced to continually cut spendings over the last couple of years. 
Table 1. Facts and figures "pro mente OÖ"

\begin{tabular}{|c|c|}
\hline Clients (2015) & 34.000 \\
\hline Employees & 1.500 \\
\hline Sites in Upper Austria & 200 \\
\hline Guidelines and principle ideas & Human rights, inclusion/ participation, prevention, empowerment, "Tetralog" \\
\hline Working fields & $\begin{array}{l}\text { Employment, capability-oriented activities, leisure time \& communication, } \\
\text { geronto-psychiatry, children/adolescents, crisis aid, work of laypersons and peer } \\
\text { counselling, mobile support and help, psycho-social counselling, } \\
\text { Addiction prevention, living, research }\end{array}$ \\
\hline Missions & $\begin{array}{l}\text { „There is no health without mental health!“ } \\
\text { „Inclusion instead of exclusion!““ } \\
\text { „It is common to be different!““ }\end{array}$ \\
\hline
\end{tabular}

As needs have been changing over the years new initiatives have been formed to implement new services, for example services for special target groups like the elderly or children, or in the field of psycho-social prevention. These new initiatives are assigned by the state or the federal provinces in form of projects, so that profit- or non profit-organisations can apply for them. The organisation with the best valued project plan is assigned the new project. The public authorities aim at more efficient and transparent projects with this method. However, there are disadvantages with this type of procurement: increasing competition and an economical and financial focus lead to declines in quality and professionality. In the end employees and clients will be affected by the pressure of reducing costs.

\section{Supply conditions in Upper Austria}

In Austria the social psychiatric supply and support of disabled people is provided by non-profit-organisations mostly. Only very little is done by profit oriented companies. Around 20 organisations accomplish the psycho-social supply in Upper Austria. One of them is pro mente OÖ, which is one of the biggest organisations within Austria. The psycho-social supply and support in Upper Austria offers the following services:

- Psycho-social counselling centres

- Addiction counselling and prevention

- Crisis aid

- Mobile care and support

- Living

- Job training and counselling

- Leisure time and communication activities

- Capability-oriented activities

Pro mente OÖ covers all the above named services. Moreover due to shareholdings and subsidiary companies pro mente OÖ offers medical psychiatric rehabilitation ("pro mente Reha") and forensic follow-up care for mentally ill offenders ("pro mente Plus") to name only two.

\section{Innovative services and projects}

pro mente OÖ constantly aims at implementing innovative ideas and projects dealing with psycho- social preand post-care. One of these projects was implemented in 2015. Due to rising numbers of migrants pro mente OÖ started a youth residence for unaccompanied underage asylum seekers ("pro mente Startbox"). 30 adolescents are currently living in this residence. Furthermore pro mente OÖ offers support for families with a mentally ill parent. This service is split up into a coaching and counselling service for parents, relatives and close reference persons ("ELCO") and one for children and adolescents ("KICO"). In addition pro mente OÖ tries to reach so called NEETs (adolescents who are "not in employment, education or training") and offers them special job trainings and support. Pro mente OÖ has its own research department ("pro mente Praevention"), in order to evaluate the social psychiatric services or to apply for public research assignments. This summer employees of this department will publish a book which provides an overview of several main topics of social psychiatry (Schöny 2017).

\section{Summery and forecast}

Upper Austria has got a wide psycho-social supply system of high quality. From the perspective of human rights the law to reach equal opportunities plays an important role in the psycho-social pre- and post-care and therefore in the daily work of pro mente OÖ. In spite of all the achievements there are still some issues in Upper Austria. It can be assumed, for instance, that an obligatory payment for certain services poses a financial and psychological burden to affected people. Furthermore, constant cuts of funding and the social budget of Upper Austria bear consequences for employees as well as clients. These consequences are not to be underestimated. Thus social psychiatry in Austria shall not only fulfil its supply mandatory. It also has to raise consciousness of social problems and to work for a better society.

\section{Acknowledgements: None.}

Conflict of interest: None to declare.

\section{Contribution of individual authors:}

Writing of the report: Dominik Gruber, Kurosch Yazdi, Werner Schöny;

Literature research: Dominik Gruber. 


\section{References}

1. BMASK Bundesministerium für Arbeit, Soziales und Konsumentenschutz: Nationaler Aktionsplan Behinderung 2012-2020. Strategie der österreichischen Bundesregierung zur Umsetzung der UN-Behindertenrechtskonvention. Wien, 2012. Available here:

https://www.sozialministerium.at/cms/site/attachments/ 1/1/5/CH2081/CMS1343116498970/120725_nap_web.pdf. Date of access: $15^{\text {th }}$ March 2017.

2. BMASK Bundesministerium für Arbeit, Soziales und Konsumentenschutz: UN-Behindertenrechtskonvention. Erster Staatenbericht Österreichs. Wien, 2010. Available here: $\quad$ https://www.sozialministerium.at/cms/site/ attachments/0/5/9/CH3141/CMS1415978600199/1_staa tenbericht_crpd_-_deutsche_fassung1.pdf. Date of access: $15^{\text {th }}$ March 2017.

3. Grausgruber A, Grausgruber-Berner R, \& Haberfellner EM: Enthospitalisierung psychiatrischer LangzeitpatientInnen in Oberösterreich. Eine Evaluierung der Versorgungskosten, des Hilfebedarfs und der Lebensqualität. pro mente edition, Linz, 2006.

4. Land Oberösterreich: Oberösterreichischer Sozialbericht 2015. Linz, 2015. Available here: http://www.land- oberoesterreich.gv.at/sozialbericht2015.htm. Date of access: 15 ${ }^{\text {th }}$ March 2017.

5. Oberösterreichische Nachrichten: Oberösterreichises Sozialbudget: Der garantierte Steigerungsposten. $25^{\text {th }}$ July 2016. Available here: http://www.nachrichten.at/nachrichten/ politik/landespolitik/Oberoesterreichisches-SozialbudgetDer-garantierte-Steigerungsposten;art383,2299355. Date of Access: $15^{\text {th }}$ March 2017.

6. pro mente Austria: Zeittafel - Die Geschichte von pro mente Austria. Available here: http://www.promenteaustria.at/de/pro-mente-austria/ geschichte/. Date of access: $8^{\text {th }}$ March 2017.

7. pro mente OÖ (ed.): 50 Jahre Helfen statt Ausgrenzen. 1964-2014. pro mente edition, Linz, 2014.

8. Schöny W (ed.): Sozialpsychiatrie. Theoretische Grundlagen und praktische Einblicke. Springer, Berlin and Heidelberg, 2017.

9. Weiß N: Die neue UN-Konvention über die Rechte von Menschen mit Behinderungen - weitere Präzisierung des Menschenrechtsschutzes. Menschen Rechts Magazin 2006; 3:293-300.

10. WHO: Ottawa Charta for Health Promotion, 1986. Available here: http://www.euro.who.int/_data/assets/ pdf_file/0006/129534/Ottawa_Charter_G.pdf. Date of access: $8^{\text {th }}$ March 2017.

\section{Correspondence:}

Mag. Dominik Gruber, Bakk. phil.

pro mente Oberösterreich, Abteilung Qualitätsmanagement

Lonstorferplatz 1, 4020 Linz, Austria

E-mail: gruberd@promenteooe.at

http://www.promenteooe.at

http://www.promentepraevention.at/ 